\title{
A Comparative Study of Family Environment and Counseling Needs among Females Gifted Students at Public Schools and King Abdullah II Schools for Excellence (KASE) in Jordan
}

\author{
Noor Talal Al. Bdour ${ }^{1, *} \&$ Muna Ali Abudarwish ${ }^{1}$ \\ ${ }^{1}$ Special Education Department, Al Hussein bin Talal University, Jordan \\ *Corresponding author: Special Education Department, Al Hussein bin Talal University, \\ Jordan. E-mail: noorbdoor@ahu.edu.jo
}

Received: September 21, 2018 Accepted: October 17, 2018 Published: November 20, 2018

doi:10.5296/ije.v10i4.13683 URL: https://doi.org/10.5296/ije.v10i4.13683

\begin{abstract}
The current study aimed at comparing family environment and counseling needs among females gifted students at public schools and King Abdullah II School for Excellence (KASE) in Ma'an city in Jordan to explore the most appropriate educational alternative. In order to achieve the study goals, a family environment and counseling needs scales were applied on a sample of $(n=107)$ students. Results showed that students' evaluation for family environment at public schools and KASE was high, while gifted students' evaluation for counseling needs at public schools was moderate and KASE was low which reflects that KASE is more appropriate educational alternative for gifted and talented female students. Results also reported a reverse relationship between each of family environment and counseling needs in both cases, although rapprochement of prevailing family environment for all gifted students, finally, a group of recommendations was provided.
\end{abstract}

Keywords: Family environment, Counseling needs, Females gifted students, Public schools, King Abdullah II School for Excellence (KASE) 


\section{Introduction}

By entering third millennium, a giant revolution invades all aspects of life as communication, transportation, technology, knowledge and education. The great and rapid development in education field made many countries concern more at their general educational strategies and programs to coincide with this universal progress, thus countries focus its concern on gifted and talented students' programs because it views them as important national resource and treasure should be invested. Renzulli (1976) defined a gifted and talented student as the student with one or more of creative abilities, motivation, and high mental capacity, and these characteristics interact and overlap with each other (Rihani, Zureiqat and Tannus, 2018), Mcclam and Pfeiffer (2012) gave a broad definition for various aspects of giftedness as those who "exhibit outstanding intellectual ability, and are capable of extraordinary performing and accomplishment"(p.59), then Peterson in (2015) describes gifted individuals as those with exceptionally high ability, regardless of academic performance (p.153), ( Kendy, Kelly and Fareley,Jessica,2018), While we adopt the definition focuses on highly academic achievement in specifying gifted and talented students as it's a certified in Jordan.

Gifted and talented students enroll into two types of education system in Jordan, the General education system represented by public schools, which present a general educational program for ordinary students, and Special education system represented by private schools for gifted and talented students as King Abdullah II School for Excellence (KASE) which presents a specialized educational programs that consider gifted and talented students' potentials and needs (The Jordanian Ministry of Education, 2005). In order to make gifted and talented students use their ultimate potentials in a productive and effective manner, interest should be available into two important psychological characteristics which are; family environment and counseling needs, these characteristics enable gifted and talented students to adapt with themselves, their family, their school and their society. Here we are trying to compare gifted and talented female students' psychological characteristics with two basic types of education systems in Jordan (public and KASE) to explore which system is more suitable and beneficial for those students.

\subsection{Statement of the Problem}

Modern trends in educational programs and curricula in general call for the inclusion of plans and guidance programs that are inseparable from them, help students to understand themselves, overcome their scholastic problems, and to explore their potentials, invest them, achieve their goals and their psychological consensus in and out of school. The general strategy of guidance and guidance services in the care of gifted and talented, especially on the basis of the survey of circumstances, variables related to their growth in their family, school and community environment, as well as the current situation of the student himself, should be established to identify the needs of both the family and the school (Abu Zetoon and Banat, 2010). Although there have been many studies on gifted and talented students, they have focused on gifted and talented students enrolled in their schools, institutions and centers.

The emphasis on the category of gifted and talented students enrolled in King Abdullah II School of Excellence has been overlooked, and despite the many research interests of this 
category of students, it has lacked the focus on the extension services, the importance of providing them to this class of students, the services they must provide, - within the knowledge of researchers - and therefore the purpose of this study is to determine the reality of counseling services provided by the guide in the King Abdullah II School of Excellence for gifted and talented students.

\subsection{Significance of the Study}

The importance of the present research lies in the fact that the gifted and talented students are the ones who make the future of societies, and the ancient civilizations have since recognized the importance of these distinguished people for their achievements and inventions. The Islamic civilization was one of the most civilizations that embodied the value of learning and nurturing learners, especially the superior ones, and the rich spend on them in honor of what God gave them of reason and understanding, as well as human investment, in the modern era, to achieve the civilized development of societies. The renaissance of societies and their development have been accompanied by the scientific development achieved by scientific research because of the "brains" that invent and fulfill according to the criteria of excellence. In this context, since the 1940s, foreign countries have given special attention to the exploration and care of these students, where private schools have been established and dedicated to them. Care programs and educational, and rehabilitation plans to accompany them on their educational track and personal, social and professional paths. In the 1990s, Renzulli's project for gifted education was best resonated.

The importance of the current study can be summarized in identifying the problems experienced by the gifted and talented students in the King Abdullah II School of Excellence in order to determine their prevalence and draw the attention of all those who have the interest, power and ability to reduce this suffering by providing their educational programs under special sections and their educational institutions, as well as provide guidance plans to accompany them in their school and social life to the best options to ensure the success and excellence for the benefit and the usefulness of their communities in the era of knowledge explosion.

\subsection{Aims and Objectives}

The study aims at comparing psychological characteristics of gifted and talented students (family environment and counseling needs) among public and KASE schools' systems in Ma'an in Jordan, in order to explore which system is distinguished by a better family environment and counseling needs characteristics, then candidates it as a suitable educational alternative system that provides a differential type of learning for gifted female students especially at their critical age of Adolescence.

\subsection{Questions of the Study}

The study seeks to answer the following questions:

1. To what extent do the gifted female students in the public schools and KASE evaluate prevailing family environment in their families?

2. What is the level of the counseling needs of the gifted female students in public 
schools and KASE in Ma'an city?

3. Is there any statistically significant difference between family environment and counseling needs among the gifted female students in public schools and KASE in Ma'an city?

4. Are there any statistically significant differences at the level of significance $(\alpha \leq$ 0.05 ) in the gifted female students' evaluations in the public schools and KASE in Ma'an city to the prevailing family environment in their families?

5. Are there any significant differences at $(\alpha \leq 0.05)$ in the level of counseling needs for the gifted female students in public schools and KASE in Ma'an city?

\subsection{Procedural Definition of Terms}

\subsubsection{Family Environment}

Involves the circumstances and social climate conditions within families, the environments can differ in many ways. For example, one obvious difference lies in the socio-economic level.

\subsubsection{Counseling Needs}

Something that provides direction or advice as to a decision or course of action, especially to students

\subsubsection{Gifted Students}

Students who give evidence of high-performance capability in areas such as intellectual, creative, artistic, leadership capacity, or specific academic fields, and who require services or activities not ordinarily provided by the school in order to fully develop such capabilities.

\subsubsection{Public Schools}

a school that is maintained at public expense for the education of the children of a community or district and that constitutes a part of a system of free public education commonly including primary and secondary schools.

\subsubsection{King Abdullah II School for Excellence}

The King Abdullah II School of Excellence is one of the leading schools that embrace talented and distinguished students in the various governorates of the Kingdom, offering a variety of teaching styles. The aim is to provide specialized educational and academic services aimed at developing the educational process for gifted and distinguished students to meet their different needs that encourage them to launch their creativity and excellence.

\section{Literature Review}

\subsection{Family Environment}

The first psychological characteristic should be taken into consideration in building gifted and 
talented educational programs is a suitable family environment, as family is the key element in developing and nurturing the excellence, Khaleel (2000) defined the family environment as a general trait of the family life, in terms of safety, sacrifice, cooperation, clarity of roles and responsibilities, forms of discipline and life system, and family patterns such as happy family, interconnected family and worried family and so on, Al-Qammash, (2017) also found that family environment of gifted and talented students may share several characteristics such as: relative small size of family, the occupation of the gifted child in the first arrangement or the only child, high educational, cultural and economic level, these suitable family environment characteristics contribute in developing giftedness and releases creativity, On other hand, family environment may differ and become unsuitable according to many factors, as family's concerns, family's educational ,social and economic level, and type of education system which is our concern here, as we are trying to compare family environment of gifted and talented students according to the education system type as public or Private (KASE) schools, and find which system is more suitable family environment for gifted and talented students.

Previous studies tackled general family environment characteristics and the importance of providing a suitable and supported family environment for gifted students, for example Hine (1991) examined home environment of gifted children in Puerto Rico city and noted that the academic achievement of students is related to the growth of several family factors as: family's pressure on the student to excel, the role of the interactive school, the educational level of the parents, family support system, the optimistic attitudes, social ties, pressure on language development, family ties, and teacher and community expectations. Other few studies reviewed family environment influence on gifted students, for example a study conducted by Chan (2005) to assess self-perceptions on a sample of gifted and talented students related to the family environment and their perspective of giftedness showed that the creativity of the gifted can be strengthened by encouraging the gifted individual to be independent, and the most important and positive variables of the family environment were leadership and family cohesion, this is in harmony with what Al Najjar (2017) recently affirmed that the psychosocial and parental compatibility among a group of gifted and ordinary students were high in general, while the psychological and parental compatibility was strong and significant for gifted students, with no differences in parental compatibility among gifted and talented students related to economic, educational level of father and number of family members or class variables, while a difference was found in psychological compatibility related to the economic level variable in favor of highest economic level, noticeably all these previous studies tackled influences and characteristics of suitable family environment on gifted and talented students in general, while we discuss family environment of gifted students deeply by contrasting it to effects of type of education system (public or private- KASE) as in the following sections.

\subsection{Counseling Needs}

The second psychological characteristic should be also taken into consideration in building gifted and talented educational programs is how to deal with student's counseling needs or problems. Counseling needs are defined by Nori and Yahya (2008) as "The desire of the individuals to express their various problems that they suffer from, and cause distress and discomfort, and how they seek to satisfy, interact and adapt positively to their environment. 


\section{Mll Macrothink}

These needs vary according to different gifted students' stages and require a suitable educational counseling curriculum. The common belief of gifted and talented students is that they have no problems in their life because of their mental superiority, and their adaptation ability with surrounding circumstances, but in fact, gifted and talented students usually encounter many problems in their life, thus counseling needs appear strongly and requiring guidance and treatment, counseling needs or problems may vary, but the most prominent problems of gifted and talented students are the emotional and social problems, because gifted students are distinguished from others, and they have characteristics of excessive sensitivity, emotional power, perfectionism, sense of difference and the unbalanced growth in some mental and social aspects (Jarwan, 2016), (Khateeb et.al, 2018).

Unlike family environment studies, several studies addressed counseling needs and emotional and social problems faced by gifted and talented students with different variables since (19892017), for example many researchers as Al-Qureaite (1989), Abu Jreas (1994), Chan (2003), Kesici (2008), Chan. David ; Chan, Lai and Zho, Youngiun, (2009), Al Jundi, (2010), Abu Hawash; Attar; Tannous et. al (2012), Al Ashoul ,(2013), Adwan and Khayat (2015) and Abu Hassouna (2016) focused on general counseling needs and different psychological, social and emotional problems faced by gifted and talented students such as: problems of leisure times and activity, lack of possibilities for practicing activities and hobbies in the school, excessive sensitivity and nervousness, boredom and lack of motivation to learn and ongoing family demanding for a higher achievement, adjustment to being gifted, perfectionism, self-concept and social adaptation, in addition to teachers' favoritism, unchallengeable curriculum of gifted students' abilities, lack of school adaptation and fear of failure, unsuitable study tasks and intense involvement parenting methods of unsuitable upbringing and highly family attitudes towards mental excellence.

Other studies tackled social and emotional problems according to different variables as the gender (male or female), a few researchers focus on counseling needs of gifted and talented students according to gender variable, as Al-Ghufile (1990), Manse (2003), Haran (2005) and Kennedy \& Forely (2017) who examined the most important problems of mental health experienced by male and female gifted and talented students, results showed that males exhibited more problems than females. the most important of these for gifted male students were: isolation and introversion, unacceptable opinions, frustration at failure, doubt and confusion and lack trust of others, external problems aspect in the relationship with family, school, friends and surrounding environment in secondary stage, self-esteem, perfectionism, while problems of gifted female students were: shyness, feeling upset when are not superior to others, and inability to fill the leisure times fear of exams, jealousy of female colleagues, lack of love by others, and quarrels with their brothers in their families.

Other studies focused on the type of education system or school as what noted by Shible (2011) and Ayasareh and El Omari (2016) of the most important social needs and problems of gifted students at king Abdullah II school for excellence: acquiring leadership skills, dealing with others, motivation, investing time well, and the need for comfort and volunteer work, while the most important emotional needs were being understood by others, self-affirmation, the need to reduce problems such as feelings of boredom, failure, anger, lack of self-confidence, anxiety 
towards future and study test. Al Remawe and Arabiat (2014) also examined the most important counseling needs for gifted and talented students at pioneers' schools: the emotional aspect, then social, family, vocational, health and finally physical needs. Hence, in this study we are trying to combine these counseling needs, psychological, social and emotional problems of gifted student as reached by previous studies and comparing them to different variables as gender (male or female) and type of education system (public or private- KASE).

\subsection{Public Schools and King Abdullah II School for Excellence (KASE)}

Since establishing the modern Hashemite kingdom of Jordan in 1921, a great interest was directed to build public schools all over the country; those schools provided different types of knowledge and information for ordinary students from first grades till secondary grades. During the last eighties decade, Jordan was distinguished by a high interest in special education system in general and gifted and talented students educational programs in particular, for example the first giftedness care program was started in (1984) known as the Pioneers Program for the gifted, this was followed by opening the Jubilee School in (1993), which used the latest methods in teaching gifted and talented students (Mayta, 2014), then the Jordanian Ministry of Education began implementing academic acceleration programs in (1997-1998), It also started using the resource rooms strategy in regular schools in (1999-2000) to provide educational environment that responds with multiple needs of the gifted and talented students.

According to the interest of his majesty king Abdullah II - King of Jordan- in providing opportunities for gifted and talented students to invest them in progress and prosperity of nation, and according to the recommendation of the educational developmental conference; king Abdullah II school for excellence (KASE) project was launched by the Ministry of Education in Jordan, KASE is a private school for distinguished, gifted and talented male and female students, distributed in different governorates of the country, the first school was opened in 2001 in Zarqa governorate, followed by another one in Irbid and Balqa' governorate in 2003, and it was opened in Ma'an governorate in 2012 (Jarwan, 2016).

KASE schools offer specialized enrichment educational services aim to develop educational process of gifted and talented students and develop their class and school environment, preparing them to be future leaders in appropriate environment, students enroll to KASE at age of 12 years ( $7^{\text {th }}$ grade), selected by careful standards criteria and gifted tests, students had extensive enrichment specialized programs in about 40 classes weekly, teaching staff undergo certain conditions of selection; as being master or doctorate degrees holders, distinction in their job performance. Educational programs and syllabus are built carefully to meet students' abilities and needs; also, gifted and talented students' families are essential partner in building gifted students' programs, KASE interests on having a continuous contact with families by giving them a feedback about students' achievement and circumstances. Educational counselors must be valuable in KASE to meet gifted students' needs and help them to solve their various problems (The Ministry of Education in Jordan, 2005) 


\section{Method}

\subsection{Participants of the Study}

A total number of (107) gifted and talented female students from public schools and King Abdullah II School for Excellence (KASE) were purposefully assigned participated in current study, (55) students from AL-Iskan Secondary school as selective public School and (52) from the KASE in Ma'an city. These students achieved the best averages of (90 and more) in their classes; they ranged from seventh to eleventh grades.

\subsection{Study Instrument}

A descriptive correlation approach was used to answer the study questions; family environment scale and counseling needs scale were used in data collection as the follows:

\subsubsection{Family Environment Scale}

Khaleel's Family Environment Scale modified by Abu Darwish, Msbheen \& Beirat (2018) was used and its psychometric properties were verified. A team of specialists in counseling, special education, and evaluation and measurement recommended using the five-point Likert's scale (from 1: very little degree to 5: very high degree) instead of the three-point scale. The verification of content validity coefficient led to excluding items that were not statistically significant at $(\alpha \leq 0.05)$ or $(\alpha \leq 0.01)$ out of the 34 original items. So, the final version of the scale was reduced to (25) items. To achieve the purposes of the current study, the scale was administered in a pilot study that included (30) students from the study population other than the main sample to verify its content validity by using Pearson correlation coefficient between the degree of one item and the total degree of the scale. Correlation coefficients between the items and the total degree of the Family Environment scale ranged from (0.393- 0.637). Using Cronbach alpha coefficient and split half method revealed the two reliability coefficients $(0.901)$ and $(0.617)$ respectively which were suitable for the study purposes.

\subsubsection{Counseling Needs Scale}

The same procedures used in Abu Darwish, et al (2018) modified scale were also applied to produce a version that included (41) items from the Counseling Needs Scale prepared by Aljundi (2010). The scale contained five points Likert scale; the same statistical procedures were used to verify the validity and reliability of Counseling Needs Scale. The content validity was calculated by using Pearson correlation coefficient between the degree of one item and the total degree of the scale. Correlation coefficients between the items and the total degree of the Counseling Needs Scale ranged from (0.361-0.778). Using Cronbach alpha coefficient and split half method revealed the two reliability coefficients $(0.927)$ and $(0.605)$ respectively which were suitable for study purposes.

\section{Results of the Study}

The following part includes a presentation of the results by answering its questions: 
Results related to the first question: To what extent do the gifted female students in the public schools and KASE evaluate prevailing family environment in their families?

To answer first question, statistical means and standard deviations for the evaluations of the sample of the gifted and talented students in both schools about the prevailing family environment in their families were calculated. The following table shows these results:

Table 1. The Statistical Means and Standard Deviations for the Evaluations of the Gifted Female Students in the Public Schools and KASE on the Family Environment Scale Items and for the Total Scale

\begin{tabular}{|c|c|c|c|c|c|c|c|}
\hline & & KASA & & & Public sch & ols & \\
\hline No. & Item & $\begin{array}{l}\text { Standard } \\
\text { deviation }\end{array}$ & $\begin{array}{l}\text { Statistical } \\
\text { means }\end{array}$ & Rank & $\begin{array}{l}\text { Standard } \\
\text { deviation }\end{array}$ & $\begin{array}{l}\text { Statistical } \\
\text { means }\end{array}$ & Rank \\
\hline 1 & $\begin{array}{l}\text { Advice and counseling are } \\
\text { the basis of guidance within } \\
\text { my family }\end{array}$ & 0.73 & 4.37 & high & 0.81 & 4.32 & high \\
\hline 2 & $\begin{array}{l}\text { My family members play a } \\
\text { role not their role }\end{array}$ & 1.22 & 3.75 & high & 1.07 & 3.13 & high \\
\hline 3 & $\begin{array}{l}\text { There is a constant working } \\
\text { within them, there are } \\
\text { rewards and punishment } \\
\text { within my family }\end{array}$ & 1.28 & 3.89 & high & 1.12 & 3.82 & high \\
\hline 4 & $\begin{array}{l}\text { My family encourages its } \\
\text { members to adhere to social } \\
\text { traditions and customs }\end{array}$ & 1.05 & 3.70 & high & 1.08 & 3.92 & high \\
\hline 5 & $\begin{array}{l}\text { Selfish and self-love prevail } \\
\text { among my family members }\end{array}$ & 0.93 & 2.81 & moderate & 1.00 & 2.80 & moderate \\
\hline 6 & $\begin{array}{l}\text { My family is working to get } \\
\text { their members to the highest } \\
\text { scientific level }\end{array}$ & 0.52 & 4.68 & high & 0.66 & 4.47 & high \\
\hline 7 & $\begin{array}{l}\text { Altruism - telling the truth - } \\
\text { respect others ... etc are } \\
\text { values we raised on them }\end{array}$ & 0.89 & 4.61 & high & 0.78 & 4.50 & high \\
\hline 8 & $\begin{array}{l}\text { We have a family dates for } \\
\text { food, visits ... etc. We take } \\
\text { care to committed by them }\end{array}$ & 1.00 & 3.96 & high & 1.17 & 3.43 & moderate \\
\hline 9 & $\begin{array}{l}\text { The problems between my } \\
\text { family members occur for } \\
\text { any simplest reasons }\end{array}$ & 1.07 & 2.21 & low & 0.94 & .382 & moderate \\
\hline 10 & $\begin{array}{l}\text { My family members comply } \\
\text { with family instructions and } \\
\text { regulations with a sense of } \\
\text { their conscience }\end{array}$ & 0.92 & 3.96 & high & 0.89 & 4.01 & high \\
\hline 11 & $\begin{array}{l}\text { "Don't postpone the work of } \\
\text { today to tomorrow" a saying } \\
\text { my family believe in }\end{array}$ & 1.17 & 3.84 & high & 1.07 & 3.93 & high \\
\hline
\end{tabular}


12 Every member of my family 1.45 has his own world

13 My family is committed to

0.88

4.38

4.44

high

modera

1.28

3.21

moderate

religion and its instructions

14 It is unknown who is the 0.82 responsible in my family

15 Everyone in my family 1.0 respects himse17lf and others

16 The problems of my father

0.62

low

1.02

moderate

and mother threaten and stress our lives

17 My father is keen to hear and 0.77

high solve every problem we are exposed to

18 Mutual conversation is our

high

1.16

4.00

high

principle in making any decision

19 Dictatorship is a feature of

1.18

2.38

moderate

1.07

moderate our family life

20 My family members share

1.07

4.06

high

1.11

4.07

high

food and clothing with all love

21 Respect the old and affection

0.99

4.02

high

1.04

4.17

high on the little is applied in my family

22 My family members work as a single unit to raise the

high

1.02

4.39

high status of the family socially and economically

23 My family members take 1.09

$4.15 \quad$ high

1.14

4.19

high care of modesty in the clothes

24 Everyone feels that they belong to the family and are

1.29

4.00

high

1.02

4.10

high keen on their unity

25 My family income is insufficient to meet their needs

General statistical means of

1.05

0.97

3.61

moderate

the prevailing family environment for the family of 0.48

high

0.59

3.73

high study sample

According to the results shown in table (1) the general statistical means of the gifted and talented students' evaluations in the public schools in Ma'an city to prevailing family environment were high (3.73), standard deviations (0.590), and the statistical means on items 
ranged between (2.44 -4.50) while the general statistical mean of the evaluations of the gifted and talented students in the (KASE) in Ma'an city to the prevailing family environment was high (3.76) and the standard deviations (0.48). The evaluation of the study sample on the total scale items showed that the statistical means values ranged from (2.21) to (4.68) .

Results related to the second question: What is the level of the counseling needs of the gifted female students in public schools and KASE in Ma'an city?

In order to answer the second question of the study, statistical means and standard deviations of the evaluations introduced by study sample on counseling needs scale items and for the total scale were calculated. This is shown in table (2).

Table 2. The Statistical Means and Standard Deviations for the Evaluation of the Gifted Female Students in Public Schools and KASE on the Counseling Needs Scale Items and for the Total Scale

\begin{tabular}{|c|c|c|c|c|c|c|c|}
\hline \multirow[b]{2}{*}{ N. } & \multirow[b]{2}{*}{ Item } & \multicolumn{3}{|l|}{ KASE } & \multicolumn{3}{|c|}{ Public schools } \\
\hline & & $\begin{array}{l}\text { standard } \\
\text { deviation }\end{array}$ & $\begin{array}{l}\text { statistical } \\
\text { mean }\end{array}$ & Rank & $\begin{array}{l}\text { standard } \\
\text { deviation }\end{array}$ & $\begin{array}{l}\text { statistical } \\
\text { mean }\end{array}$ & Rank \\
\hline 1 & Overcoming my moody cases & 1.02 & 2.23 & low & 1.00 & 2.34 & moderate \\
\hline 2 & $\begin{array}{l}\text { How to develop my skills and my } \\
\text { ways of thinking }\end{array}$ & 1.15 & 2.49 & moderate & 1.08 & 2.82 & moderate \\
\hline 3 & $\begin{array}{l}\text { How to plan the study and prepare } \\
\text { lessons }\end{array}$ & 1.19 & 2.54 & moderate & 1.33 & 2.59 & moderate \\
\hline 4 & Face the boredom of the lessons & 1.11 & 3.34 & moderate & 1.15 & 2.73 & moderate \\
\hline 5 & How to organize my time & 1.24 & 2.44 & moderate & 1.04 & 2.78 & moderate \\
\hline 6 & How to develop my thoughts & 1.10 & 2.45 & moderate & 1.05 & 2.89 & moderate \\
\hline 7 & How to spend the leisure time & 1.06 & 2.40 & moderate & 1.07 & 2.68 & moderate \\
\hline 8 & $\begin{array}{l}\text { How to face my excessive } \\
\text { sensitivity }\end{array}$ & 1.10 & 2.15 & low & 1.12 & 2.58 & moderate \\
\hline 9 & How to deal with my colleagues & 1.07 & 2.10 & low & 1.22 & 2.21 & low \\
\hline 10 & How to do different school activities & 1.02 & 2.29 & low & 1.05 & 2.41 & moderate \\
\hline 11 & How to face shyness & 1.21 & 2.31 & low & 1.14 & 2.55 & moderate \\
\hline 12 & How to express my opinion freely & 0.90 & 2.06 & low & 1.15 & 2.52 & moderate \\
\hline 13 & $\begin{array}{l}\text { How to develop curiosity and } \\
\text { explore the environment }\end{array}$ & 1.01 & 2.31 & low & 1.10 & 2.50 & moderate \\
\hline 14 & How to deal with teachers & 1.10 & 2.10 & low & 1.28 & 2.35 & moderate \\
\hline 15 & Eliminate loneliness & 1.14 & 2.04 & low & 1.25 & 2.13 & low \\
\hline 16 & Face disconcertion in the lessons & 1.27 & 2.09 & moderate & 1.12 & & 2.22 \\
\hline 17 & $\begin{array}{l}\text { Confronting the problem of } \\
\text { inappropriate curriculum }\end{array}$ & 1.05 & 2.22 & low & 0.90 & 2.26 & low \\
\hline 18 & Help me to make friends & 1.21 & 1.90 & low & 1.10 & 2.07 & low \\
\hline 19 & $\begin{array}{l}\text { Help me to deal with my brothers } \\
\text { and family }\end{array}$ & 1.04 & 1.71 & low & 1.19 & 2.09 & low \\
\hline
\end{tabular}


21 Help me to overcome my health 0.86 problems

22 Help me to deal with people in 0.95 society

23 Help me in solving my emotional 0.94 problems

24 Help me to facing high expectations 0.98 of parents

25 Help me to overcome the feeling of 1.13 neglect

26 Help me to act in social situations $\quad 1.04$

27 Help me to overcome the 1.06 unaccountable adventure

28 Develop my hobbies

29 Help me to in interact with others

1.88

1.76

1.96

1.80

1.81

2.09

2.06

2.17

1.04

30 Planning what I will be in the future

1.26

31 Provide the necessary tools and 1.08 materials I need it

Dvercoming the feeling of
persecution and discrimination in school

33 Overcoming sleeplessness problems

34 No one understand and cares about me

35 Teachers' contempt for my thoughts

Overcoming the feeling of persecution and discrimination at home

37 My sense of security and non-threat

1.00

1.63

2.18

1.73

0.91

1.76

1.67

low

1.06

2.24

2.81

2.45

2.87

2.29

ISSN 1948-5476

2018, Vol. 10, No. 4

38 The contempt of the family with my

0.84 thoughts

39 Overcoming school routines

low

1.40

2.32

low

$$
\text { low }
$$

0.80

1.59

low

40 Adapt to the school environment

2.66

moderate 1.22

2.82

moderate

2.35

moderate

1.14

2.41

moderate

41 Overcoming

- General statistical means of the 0.61
2.17

embarrassing $\quad 1.23$

situations

2.56

moderate counseling needs among students

According to results shown in table (2), General statistical means of counseling needs for gifted and talented students in public schools in Ma'an city was moderate (2.38) and the standard deviation (0.75), the statistical means values on items ranged (2.89-1.59). However, the general statistical mean of gifted and talented students at the KASE in Ma'an was low (2.11) and the 
standard deviations $(0,61)$.

Results related to the third question: Is there any statistically significant difference between family environment and counseling needs among the gifted female students in public schools and KASE in Ma'an city?

In order to discover the difference between family environment and counseling needs; the correlation relationship between the total level of the prevailing family environment among gifted and talented students in public schools and King Abdullah II School for Excellence in Ma'an was determined, and the total level of their counseling needs. Table (3) shows this:

Table 3. Correlation Coefficient between the Family Environment and Counseling Needs among Gifted and Talented Students in the Public Schools and KASE

\begin{tabular}{lllll}
\hline Variable & \multicolumn{3}{l}{ Counseling needs } & \\
\cline { 2 - 5 } & $\begin{array}{l}\text { Students at } \\
\text { school }\end{array}$ & & & \\
\hline Family & Statistical & correlation & Statistical & correlation coefficient \\
environment & Significance & coefficient & Significance & \\
& 0.023 & $*_{-} 0.209$ & 0.000 & $* *_{-} 0.311$ \\
\hline
\end{tabular}

** Statistical at the level of significance $(\alpha \leq 0.01)$

* Statistical at the level of significance $(\alpha \leq 0.05)$

The results in Table (3) show that there is a negative relationship between family environment and counseling needs of gifted and talented students in public schools, the correlation coefficient was (- 0.311) which is a statistically significant at the level of significance $(\alpha \leq 0.01)$, also there was a negative relationship between the family environment and the counseling needs of gifted and talented students in the King Abdullah II School for Excellence, the correlation coefficient was (-0.209) which is a statistically significant at the level of significance $(\alpha \leq 0.05)$. To detect the significance of the differences in the level of the relationship, Fisher Z-test was performed to test the differences between the correlation coefficients as shown in Table (4).

Table 4. The results of Fisher Z-test to test the significance of the differences between the correlation coefficients among the total level of the family environment and the counseling needs of gifted and talented students in the public schools and KASE

\begin{tabular}{lll}
\hline Variables & Counseling needs \\
\cline { 2 - 3 } & KASE Students & $\begin{array}{l}\text { Students at the public } \\
\text { schools }\end{array}$ \\
\hline Family Environment & $\begin{array}{l}\text { correlation coefficient } \AA \\
\text { correlation coefficient } \AA\end{array}$ \\
Fisher $(Z)$ value & $* * 2.91$ & \\
Statistical Significance & 0.00 & \\
\hline
\end{tabular}

** Statistical at the level of significance $(\alpha \leq 0.05)$ 
The results in Table (4) show that there was a statistically significant difference at the level of significance $(\alpha \leq 0.01)$ in the correlative relationship between the total level of family environment and counseling needs of gifted and talented students in the public schools and KASE, where the value of the Fisher $(Z)$ was $(2.91)$, which is statistically significant at the level of significance $(\alpha \leq 0.01)$. The relationship between the total level of family environment and counseling needs of gifted and talented students in public schools was statistically significant stronger than that of gifted and talented students at KASE.

Results related to the fourth question: Are there any statistically significant differences at the level of significance $(\alpha \leq 0.05)$ in the gifted female students' evaluations in the public schools and KASE in Ma'an city to the prevailing family environment in their families?

To answer this question, T. Test was performed as shown in table (5).

Table 5. T- test Results of the Differences Significance between the Means of Gifted and Talented Students' Appreciations in the Public Schools and KASE in Ma'an City to the Prevailing Family Environment in Their Families

\begin{tabular}{llllll}
\hline Category & Number & $\begin{array}{l}\text { Statistical } \\
\text { Significance }\end{array}$ & $\begin{array}{l}\text { T } \\
\text { Value }\end{array}$ & $\begin{array}{l}\text { standard } \\
\text { deviation }\end{array}$ & statistical mean \\
\hline $\begin{array}{l}\text { Students at the public } \\
\text { schools }\end{array}$ & 0.521 & 0.641 & 0.59 & 3.73 \\
$\begin{array}{l}\text { Students at the } 52 \\
\text { excellence schools }\end{array}$ & & & & & \\
\hline
\end{tabular}

The results of Table (5) show that there are no differences in how gifted and talented students in public schools and KASE in Ma'an city evaluate prevailing family environment in their families, based on the significance of the calculated $(\mathrm{T})$ value $(0.641)$, which is not statistically significant at (0.05), Indicating the rapprochement in the prevailing family environment among students in the public schools and KASE in Ma'an.

Results related to the fifth question: Are there any significant differences at $(\alpha \leq 0.05)$ in the level of counseling needs for the gifted female students in public schools and KASE in Ma'an city?

To answer this question, T. Test was performed as shown in table (6).

Table 6. T- Test Results of Significance Differences between the Means of Responses of Gifted and Talented Students in the Public Schools and KASE in Ma'an City to Their Counseling Needs

\begin{tabular}{llllll}
\hline Category & Number & $\begin{array}{l}\text { Statistical } \\
\text { Significance }\end{array}$ & $\begin{array}{l}\text { T } \\
\text { Value }\end{array}$ & $\begin{array}{l}\text { standard } \\
\text { deviation }\end{array}$ & $\begin{array}{l}\text { statistical } \\
\text { mean }\end{array}$ \\
\hline Students at the public schools & 55 & 0.010 & $2.605^{*}$ & 0.75 & 2.38 \\
Students at the excellence school & 52 & & & 0.84 & 2.11 \\
\hline
\end{tabular}


The results in Table (6) indicate that there are statistically significant differences of the (T) value (2.605) in how students evaluate their counseling needs in favor of gifted and talented students in public schools at $(\alpha \leq 0.05)$, with higher statistical mean of (2.38), and a minimum statistical mean of (2.11) for gifted female students in KASE.

\section{Discussion}

Results showed that the evaluation of gifted and talented students for the family environment in both public schools and KASE was high; this result reflects the importance of family environment and its role in enhancing giftedness and talent. Coherent, suitable family environment and the psychological compatibility between the parents support the giftedness and excellence of female and male children and help them become more independent and increase their level of achievement. This result is consistent with the results concluded by (Hawkins, 1993; Chan, 2005; Al-Najar, 2017). The level of counseling needs ranged from moderate among students in public schools to low degree among students in KASE. The most prominent counseling needs that expressed a moderate degree level were time management problems, development of thinking, coping with boredom, leisure times spending, planning to study for the future, adapt to the school environment and overcome school routine and face embarrassing situations. The lack of understanding for the needs of the gifted and talented students especially females by the administration and the teaching staff in public schools and their inability to deal with them may be the reason for the students' suffering in these schools as Chan (2005) and Kennedy, K and Forely, J (2017) refer to. In fact, this is a strong indication that public school staff lack the proper qualification in the field of giftedness and talented students programs in public schools compared to the excellence school (KASE) students who have less counseling needs at their critical adolescences age which is the key interest of KASE which receive students at the beginning of adolescent age 12 year, thus it is considered as appropriate alternative education system for gifted students especially females, KASE uses all its potentials to take care of their students, prevent and overcome the problems they encounter by well-trained educational counselor who cope with students' difficulties, this is significantly supports the results by (Abu-Jreas, 1994; Manse, 2003; Jundi, 2010; Shible, 2011 Ashoul ,(2013), Adwan and Khayat (2015). As reported by Al-Qummash (2017) this result may also reflect one of the most significant characteristics of the gifted students: the high-level ability to face and solve their problems. The inverse relationship between the family environment and the counseling needs explains that whenever a suitable family environment is available for female students featured in safety, cooperation, control and a high socio-cultural and economic level, the problems are reduced and therefore the female counseling needs are reduced too. This indicates the importance of activating the role of family in supporting gifted students, at this regard (Hine, 1991) asserted the importance of family factor for developing the student's academic achievement; and (Chan,2003) emphasized the importance of (SAPI18) list to assess the gifted control problems.

Similar social structure of the city population explains why the gifted and talented students in both schools evaluate the family environment almost in the same way. Most families seek to 
provide a safe and supportive environment for their gifted children. Qummash (2017) found out that families of gifted and talented students have many characteristics in common such as small size and relatively high educational, cultural and economic level.

The level of counseling needs among female gifted and talented students in the public schools is statistically significant compared to those in the excellence school, this is because the Excellence School is a special school for gifted and talented students that is supposed to provide an increased interest in providing an appropriate tools and methods for gifted and talented students and in providing a supported environment in excellence in scientific, academic and technical fields, with focus in family partnership in setting educational programs with a skillful consolers in students' demands and problems. In addition to expressing a higher level for counseling needs, (Al-Qureaite, 1989, Al- Ghufile, 1990, Tannos et. al, 2012, Abu Hawash, 2012, Abu Hassoun, 2016) pointed out that students in public schools also suffered some academic problems. Some emotional problems appear more among gifted and talented students at public schools such as problems of loneliness, shyness, and lack of sense of security due to the lack of concentration of these schools to meet their counseling needs which is a result that goes in line with the studies of (Shible (2011), Attar (2012), AL Remawe and Arabiat (2014), Adwan \& Khayat, (2015) and Ayasareh and El Omari (2016).

\section{Conclusion}

The current study compared the family environment and the counseling needs among the gifted and talented students in public schools and KASE in Ma'an. The comparison showed similarities and differences between general and the special educational systems, the similarities in the appreciations of all gifted female students for family environment were high, the results also showed a rapprochement in the family environment of both educational systems because the similar geographical and social environment characteristics.

Counseling needs of female gifted and talented students differed by type of school, the students' perceptions of counseling needs in public schools were moderate and for the students of the KASE were low, which reflects less attention paid by public schools in facing gifted students' problems, in contrast to the special education system as in KASE which gives gifted and talented students category only its focus and attention, thus it is considered more appropriate to gifted students than public schools.

The nature of relationship between family environment and counseling needs is determined by the inverse relationship, the high and positive level of the family environment reduces the counseling needs of the gifted students. Finally, the study recommends the need to develop family counseling programs for gifted and talented students, and emphasize the interactive role of the gifted family in developing giftedness programs, choosing the most appropriate educational alternative system that meets the needs of gifted students, and supporting the schools of gifted and talented students such as King Abdullah II (KASE) which meets counseling needs of the gifted and talented students and develops their creativity and energies. 


\section{Acknowledgement}

Special thanks for AL-Iskan public Secondary school and King Abdullah II School for Excellence (KASE) in Ma'an for their cooperation.

\section{References}

Abu Darwish, M., Msbheen, M., \& Beirat, M. (2018) The Relationship Between Family Environment and Counseling Needs of Talented Students in The State School in The City of Ma'an. Under publishing study, Al Hussein bin Talal University journal for researches.

Abu Hassouna, N. (2016). Problems of gifted and talented students in the province of Irbid according to a number of variables. Journal of the University of Hebron Research, 11(1), 159-187.

Abu Hawash, M. (2012) Problems of the gifted and talented students in al Bahah region from their point of view. The international specialized journal of education, 1(1), 1-16.

Abu Jreas, F. (1994). The Difference in the Problems and counseling Needs among Distinguished and Non-Distinguished Students. Unpublished Master Thesis, University of Jordan, Amman.

Abu Zeetoon,Jamal \& Banat Suhela. (2010). Phycological adaption and its relationship with solving problems skills among gifted and talented students. Phycological and educational sciences journal, 11(2), 39-64.

Adwan, F., \& Khayat, M. (2015). Cognitive and emotional needs of the gifted and talented students from themselves perspective: Survey. Candian social sciences, 11(7), 38-48.

Attar, S. (2012). Problems of gifted and talented students in the Algerian School, A survey Study in the Secondary Schools of Telemsan. Journal of Humanities and Social Sciences, 8, 169-200.

Al Ashoul, A. (2013). The problems that gifted and talented students suffered from at AL Methaq School. Arab journal to develop giftedness, 6, 109-136

Al Ghufile, Gh. (1990). Psychological needs and problems of mentally gifted students: a study on a sample in a late childhood. Unpublished master thesis, Faculty of Education, King Saud University, Saudi Arabia.

AL Haran, A. (2005). The problems of gifted and talented students at secondary stage in Kuwait country. Unpublished master thesis, Arab Amman university for higher studies. Amman. Jordan.

Al Jundi, N. (2010). Psychological Counseling Needs of Gifted and Mentally Children in Upper Primary Schools in Hebron Governorate. Journal of the Hebron University for Research, 5(1), 1-23.

Al Khateeb, J., Smadi. J., Roussan, F., Al Hadidi, M., Yahya, Khawla., Natour, M., Zureiqat, I., Amayreh, M., \& Srour, N. (2018). Introduction in Teaching Special Needs Students (8th Ed.). Dar alfikr for Publishing and Distribution, Amman, Jordan. 
Al Maytah, -Kh \& Albualez, M. (2014). Talent and Giftedness (5th Ed.). Dar alfikr for Publishing and Distribution, Amman, Jordan.

Al Najjar, N. (2017). Family harmony and psychological adjustment among gifted and ordinary student. International Journal of Education, 9(1), 1-18. https://doi.org/10.5296/ije.v9i1.10365

Al Qammash, M. (2017). Introduction to talent and mental giftedness (4th Ed.). Dar Al massira for Publishing and Distribution, Amman.

Al Quraiti, A. (1989). Mentally gifted: their problems in the family and school environment, and the role of psychosocial services in their care, the message of the Arabian Gulf, 9(28), 29-58.

AL Remawe, S., \& Arabiat, A. (2014). The counseling needs for gifted and talented students at the pioneers center in Balqa' governate and its relationship with some variables. Journal of Educational Sciences, 2, 2-25.

Al ysareh, M., \& El Omari, A. (2016). Problems of gifted and talented students at king Abdullah II School for excellence: students' perspective. International journal of education and practice, 45-70. https://doi.org/10.18488/journal.61/2016.4.2/61.2.55.70

Chan, D. (2003) Assessing adjustment problems of gifted and talented students in Hong Kong: the development of the student adjustment problems inventory. Gifted child quarterly, 47(2), 107-117. https://doi.org/10.1177/001698620304700202

Chan, D. (2005). Family environment and talent development of Chinese gifted and talented students in Hong Kong. Gifted child quarterly, 49(3), 211-221. https://doi.org/10.1177/001698620504900303

Chan, D., Chan, L., \& Zho, Y. (2009) Twenty- five years of gifted education research in Hong Kong, Educational Research Journal, 24(1), 135-164.

Hine, C. (1991). The home environment of gifted Perto Rican children: Family factors which support high achievement. Doctoral Dissertations, University of Connecticut

Jarwan, F. (2016). Talent and giftedness (7th Ed.). Dar Al Fikr for Publishing and Distribution, Amman, Jordan

Jordan Ministry of Education (2005) king Abdullah school for distinction KASD. Retrieved from http://www.moe.Gov.jomnbvcx

Kendy, K., \& Fareley, J. (2018). Counseling gifted students: school-based consideration and strategies. International Electronic Journal of Elementary Education, 10(3), 361-367. https://doi.org/10.26822/iejee.2018336194

Kesici, S. (2008). Sixth, seventh, and eighth grade students: Guidance and counseling needs according to parent's view. Eliraisian journal of educational research, 32, 101-116.

Khaleel, M. (2000). The Psychology of the Family Relations (1st Ed.). Dar Qebaa for Publishing and Distribution, Cairo.

Khaleel, M. (2006) Family environment in its relation to son's mental health. Journal of College of Basic Education, AL-Mustansyriah University, 49, 483-507 
Manse, M. (2003). Creativity and talent in the public education. Dar Al-Maarifah, Egypt.

Nuri, A., \& Yahia, I. (2008) The Psychological, Social and Educational Counseling Needs of the Students of Mosul University, Journal of Education and Science, 15(3), 294-321.

Rihani, S., Zureiqat, I., \& Tannous, A. (2018). Counseling of the special needs and their families (4th ed.). Dar alfikr for Publishing and Distribution, Amman.

Shible, R. (2011) Assess the extent to which social and emotional needs of gifted and talented students from their point of view in the talented schools, Unpublished Master Thesis, University of Jordan, Amman, Jordan.

Tannous, A., Rihani, N., \& Zbon, S. (2012) Personality that distinguish between gifted and talented students and ordinary. Dirassat journal, 39(1), 119-134.

\section{Copyright Disclaimer}

Copyright for this article is retained by the author(s), with first publication rights granted to the journal.

This is an open-access article distributed under the terms and conditions of the Creative Commons Attribution license (http://creativecommons.org/licenses/by/3.0/). 